\title{
ФОРМИРОВАНИЕ ПОДЗЕМНЫХ ВОД В ПОЗДНЕЧЕТВЕРТИЧНОЕ ВРЕМЯ НА СЕВЕРО-ВОСТОКЕ РОССИИ
}

\author{
Глотов В. Е. \\ ФГБУН Северо-Восточный комплексный НИИ им. Н. А. Шило ДВО РАН, г. Магадан \\ E-mail: geoecol@neisri.ru
}

\begin{abstract}
По данным палеогеографических и гидрогеологических исследований описаны особенности питания и разгрузки подземных вод в позднеплейстоценовый криохрон и голоценовый термохрон. Выделены режимы: регрессивный, в период от 100 до 18 тыс. л. н., отличавшийся региональной сработкой ресурсов воды в недрах; ингрессивный в период 18-9 тыс. л. н. с преобладанием восполнения водных ресурсов без их сработки и современный равновесных процессов питания и разгрузки подземных вод.
\end{abstract}

Ключевые слова: Северо-Восток России, подземные воды, поздний плейстоцен, криохроны, термохроны, палеогидрогеология.

DOI: 10.34078/1814-0998-2020-2-22-33

\section{ВВЕДЕНИЕ}

Позднечетвертичное время (поздний плейстоцен и голоцен) является временем геологически очень быстрых переходов климата от сухого, очень холодного, сопровождаемого понижением уровня Мирового океана до 150 м ниже современного, до умеренно влажного с повышением уровня моря на 25-30 м выше современного. Это же время известно как неотектонический этап дифференцированных движений, сформировавших современную геоморфологическую структуру орогенных поясов на Северо-Востоке России (Смирнов, 2012). Происходившие глобальные процессы преобразований природной среды сказывались в изменениях условий распространения и залегания, питания и разгрузки подземных вод. Эти изменения приводили к возникновению в водоносньх комплексах и зонах скоплений подземных вод, гидрогеостатические и гидрогеохимические показатели которых не соответствуют современным природным факторам формирования подземных вод в тех же водоносных комплексах и зонах. Их правомерно называть парадоксальными показателями. Такие скопления были вскрыты буровыми скважинами и горными выработками при поисках и разведке месторождений полезных ископаемых (рис. 1).

Гидрогеологическая значимость позднечетвертичных событий на Востоке Сибири и СевероВостоке России (СВ РФ) показана в работах В. Ю. Абрамова (2014), С. В. Алексеева (2009),

(C) Глотов В. Е., 2020
Л. П. Алексеевой (2015), Г. Д. Гинзбурга и др. (1971), Т. Н. Елисафенко (1988), Я. В. Неизвестнова (1981), С. М. Фотиева (2009), В. В. Шепелева и др. (1984). Однако общее видение процесса формирования подземных вод на СевероВостоке России в позднечетвертичное время до сих пор отсутствует. Вместе с тем знание его особенностей в геологически недавнем прошлом необходимо для прогноза возможных геоэкологических последствий и изменений ресурсного потенциала подземных вод при наблюдаемых глобальных природных преобразованиях (Боревский и др., 2014), решения отдельных вопросов в общей проблеме междисциплинарных исследований криосферы (Мельников, 2014).

Цель статьи - обобщить данные о подземных водах с парадоксальными показателями на СВ РФ, выявить особенности питания и разгрузки подземных вод в период позднеплейстоценголоценовых трансформаций климата и колебаний уровня Мирового океана.

Научная актуальность этой цели определяется ее соответствием Программе фундаментальных научных исследований Российской академии наук на 2013-2020 гг., направлению 76 «Поверхностные и подземные воды суши..., процессы формирования, динамика и механизмы природных... изменений...».

Практическая значимость нами усматривается в том, что полученные результаты могут быть использованы для совершенствования моделей процессов формирования подземных вод и более обоснованного применения интегрированного управления водными ресурсами в аркти- 


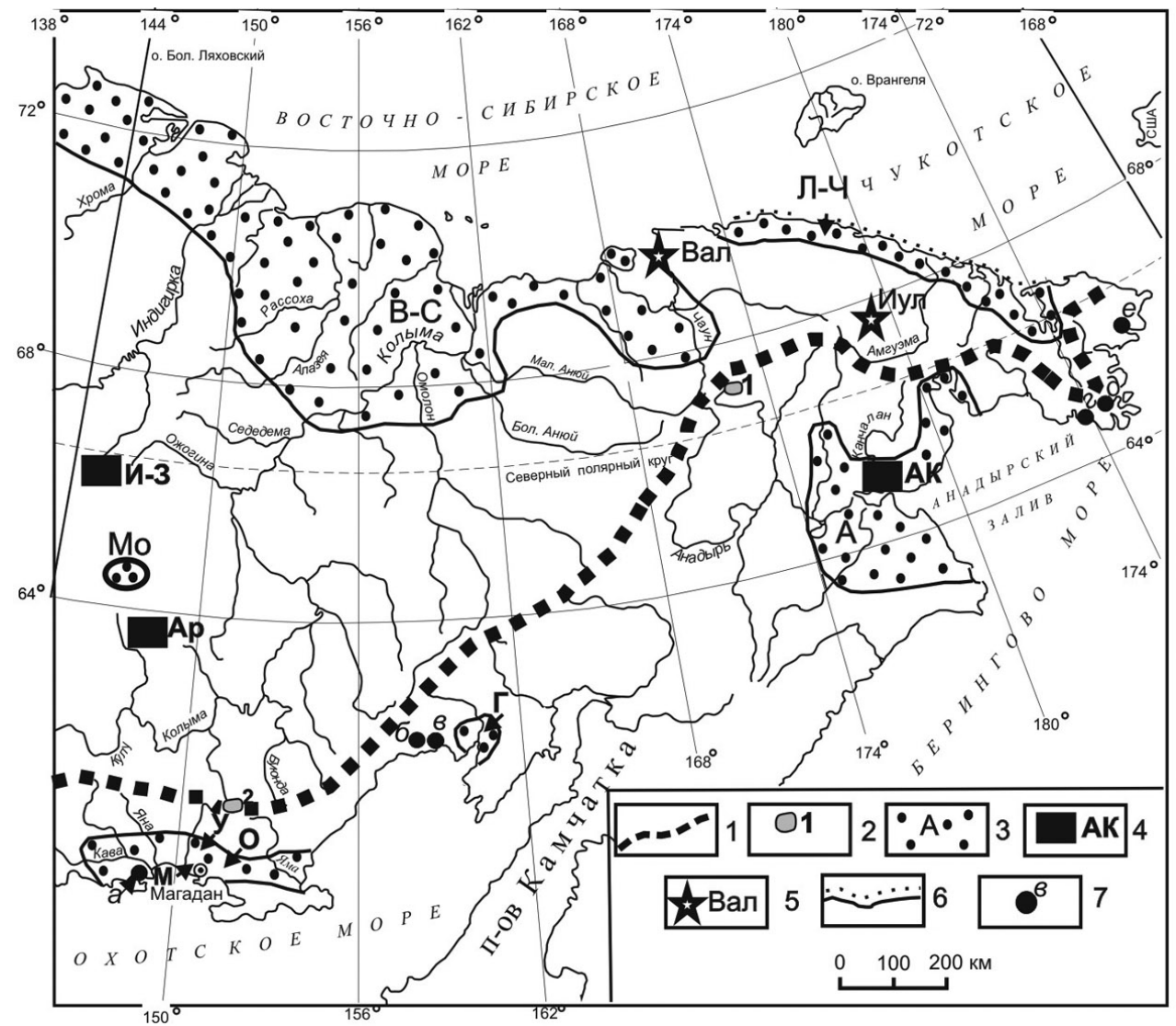

Puc. 1. Схема объектов изучения палеоклиматических изменений и их гидрогеологических последствий: 1 - Главный водораздел Земли (ГВ3); 2 - озера: 1 - Эльгыгытгын, 2 - Эликчанское. Гидрогеологические объекты с парадоксальными показателями: 3 - артезианские бассейны на тихоокеанском склоне: А - Анадырский, АК - Казачкинская впадина в составе Анадырского; Г - Гижигинский, О - Ольский, У - Уптарский, М - Магаданский; на атлантическом (арктическом) склоне: Ар - Аркагалинский, В-С - Восточно-Сибирский, Л-Ч Лонго-Чукотский, Мо - Момонтайский; 4 - отрабатываемые угольные бассейны: АК - Анадырский (Казачкинский), Ар - Аркагалинский, И-3 - Зырянский; 5 - рудные месторождения в пределах гидрогеологических массивов: Вал - Валькумейское, Д - Дегдекан, Иул - Иультинское; 6 - артезианские бассейны с проявлениями талассогенных хлоридных вод (морские побережья с линзами криопэгов и аномально низкими уровнями подземных вод); 7 - источники хлоридных термальных вод: $a$ - Мотыклейские, $\sigma$ - Березовый, 8 - Таватумский, 2- Чаплинские, $\partial$ - Кукунский, $e$ - Кивакский

Fig. 1. Schematized map objects studied for paleoclimatic changes and their hydrogeological consequences: 1 - the Great Earth Divide (GED); 2 - lakes: 1 - Lake El'gygytgyn, and 2 - Lake Elikchan. Hydrogeological objects with paradoxical indicators: 3 - artesian basins on the GED Pacific slope: A - Anadyr, АК - Kazachka Depression, included in the Anadyr basin, $\Gamma$ - Gizhiga, O - Ola, Y - Uptar, M - Magadan; on the Atlantic (Arctic) slope: Ap - Arkagala, B-C - East Siberia, Л-Ч - Longo-Chukotka, Mo - Momontay; 4 - mining coal basins: AK - Anadyrsky (Kazachkinsky), Ap - Arkagalinsky, И-3 - Zyryansky; 5 - hydrogeological massifs within ore deposits: Вал - Valkumey, Д - Degdekan, Иул - Iultin; 6 - artesian basins containing thalassogenic chloride waters; 7 - thermal chloride water sources: $a$ - Motykley, $\sigma$ - Beryozovy,, - Tavatum, 2 - Chaplin, $\partial-$ Kukun, $e-$ Kivak

ческих и субарктических районах при изменяющихся природных обстановках.

Методы и материаль исследований. Основной метод, использованный нами, это сравнительно-исторический, который включает:

выявление в подземной гидросфере «следов прошлого» как результатов преобразования природных факторов формирования подземных вод;

сопоставление с современными показателями, связанными с существующими условиями питания и разгрузки подземных вод, и воссоздание событий и явлений в геологическом прошлом; выделение основных этапов становления и развития гидрогеологических обстановок в позднем плейстоцене при глобальных изменениях климата, уровня Мирового океана, мощности и степени прерывистости криолитозоны.

Материалами для исследования послужили результаты многочисленных геологических, гидрогеологических и геокриологических работ на СВ РФ, выполненных специалистами различных научных и производственных организаций. Важные данные об изменениях позднечетвертичного климата получены при палино- 
логических и радиоуглеродных изучениях озерных осадков на СВ РФ, которые осуществлялись в СВКНИИ ДВО РАН по Международным проектам. В качестве опорных (репрезентативных) пунктов для Северо-Востока России приняты оз. Эльгыгытгын (абс. высота 489 м) и оз. Эликчанское-4 (абс. высота 800 м). Оба они расположены в зоне Главного водораздела Земли (ГВЗ), поэтому палеоклиматические реконструкции по донным осадкам этих озер отражают особенности изменения климата как на арктическом, так и тихоокеанском склонах ГВ3 (Noland et al., 2013).

Для оценки величины атмосферных осадков в прошлом мы использовали эмпирическую формулу С. Я. Сергина и М. С. Щегловой:

$$
\mathrm{A}=670 \cdot \mathrm{S}^{-0.63}
$$

где А - амплитуда годового хода температуры, $\mathrm{S}$ - годовое количество осадков (Сергин, Щеглова, 1976).

Преобразуя эту формулу, получим:

$$
\mathrm{S}=30600 \mathrm{~A}^{-1.587} \text {. }
$$

Объект исследования - климатические условия и уровень Мирового океана в позднем плейстоцене и голоцене на СВ РФ.

Предмет исследования - современные геокриологические и гидрогеологические показатели позднечетвертичных глобальных изменений природной среды в гидрогеологических структурах региона.

\section{ХАРАКТЕРИСТИКА ОБЬЕКТА ИССЛЕДОВАНИЙ}

Расположение СВ РФ в зоне смыкания Северного Ледовитого и Тихого океанов предопределило современные климатические различия арктического и тихоокеанского склонов Главного водораздела Земли. Эти различия обусловлены тем, что температура воздуха и осадки на арктическом склоне (АС ГВЗ) определяются поступлением тепла и влаги из акватории Северного Ледовитого океана, который даже в теплое время года закрыт льдами почти на 90\%. Климат на тихоокеанском склоне (ТС ГВ3) зависит от субмеридиональных циклонов, несущих тепло и влагу из субтропических и умеренно теплых районов Тихого океана.

На АС ГВЗ повсеместно среднегодовые температуры воздуха не поднимаются выше $-9.5^{\circ} \mathrm{C}$, опускаясь во внутриконтинентальных районах до $-17.1^{\circ} \mathrm{C}$. Среднемноголетние значения атмосферных осадков за год находятся в пределах 220 350 мм. Криолитозона, или криогенный водоупор (КВ) по С. М. Фотиеву (2013), имеет сплошное распространение. Мощность его на водоразделах 350-550 м, в долинах рек - 150-180 м.

На ТС ГВ3 по всей площади среднемноголетняя температура воздуха не опускается ниже $-9.5^{\circ} \mathrm{C}$. Среднее многолетнее количество осадков в год 300-550 мм. КВ в бассейнах р. Пенжина и рек, впадающих в Анадырский залив Берингова моря, слабопрерывистый, мощностью на водоразделах до 500 м, в долинах рек - 100-120 м. На остальной площади, включая и северное побережье Охотского моря, КВ прерывистый, мощностью на водоразделах до 350 м. На побережье зал. Корфа Берингова моря КВ приобретает островной характер, при мощности менее 100 м (Фотиев, 2013).

Используя современные сведения о среднемесячных температурах за январь $\left(\mathrm{T}_{\mathrm{I}}\right)$ и июль $\left(\mathrm{T}_{\mathrm{VII}}\right)$ и о среднегодовых температурах воздуха ( $\left.\mathrm{T}_{\mathrm{r}}\right)$, полученные на метеостанциях по всей площади СВ РФ Колымским управлением гидрометеослужбы (КУГМС), можно получить прямую связь отношения $\frac{\mathrm{T}_{\mathrm{I}}+\mathrm{T}_{\mathrm{VII}}}{2}$ со среднегодовой температурой воздуха. Связь выражается уравнением:

$$
\mathrm{T}_{\mathrm{r}}=1.0264 \cdot \frac{\mathrm{T}_{\mathrm{I}}+\mathrm{T}_{\mathrm{VII}}}{2}-0.7038 .
$$

Коэффициент детерминации $\left(\mathrm{R}^{2}\right)$ равен 0.9749

Следовательно, можно достаточно точно рассчитать среднегодовую температуру воздуха в прошлом, используя данные о средних месячных температурах января и июля, полученные при изучении донных осадков на СевероВостоке России (Андерсон, Ложкин, 2004). При этом авторы использовали метод аналогов, т. е. по специальной компьютерной программе каждому спорово-пыльцевому спектру находили современный аналог с известными климатическими характеристиками. Сходимость спектров статистически оценивалась как «очень хорошая», «хорошая», «возможная» и «сходство отсутствует». Среднегодовые температуры мы рассчитывали по пробам, для которых сходимость соответствовала современным аналогам как «очень хорошая» и «хорошая». Пробы с такими статистическими оценками находятся в интервалах, временные показатели которых соответствовали современному и казанцевскому термохронам. С учетом малого уровня сходимости спектров спорово-пыльцевых анализов проб из интервалов, соответствующих ледниковым периодам, для расчета среднегодовых температур мы приняли среднемесячную январскую температуру, полученную при изотопном анализе повторножильных льдов возраста от 25 до 34 тыс. лет (Васильчук и др., 2018). Она равна $-46^{\circ} \mathrm{C}$, среднемесячную температуру июля для конкретного интервала заимствовали из работ (Андерсон, Ложкин, 2004; Матросова и др., 2004).

По рассчитанным значениям $\mathrm{T}_{\text {г }}$ во временной отрезок от 140 тыс. лет до наших дней построена диаграмма многолетнего изменения одного из основных климатических параметров (рис. 2). 
На графике отчетливо выделяются два термохрона - современный с 12.2 тыс. л. н. и казанцевский в интервале 132-100 тыс. л. н. и один криохрон в интервале около 100-12.2 тыс. л. н.

Казанцевский термохрон отличался высокой среднегодовой температурой воздуха, примерно на $5^{\circ} \mathrm{C}$ выше современной. В то время на берегах Восточно-Сибирского моря и его островах произрастали древесные формы растений, ныне распространенные более чем на 200-300 км южнее (Васьковский, Терехова, 1970). Длительность самого теплого периода около 30 тыс. лет. КВ на побережье арктических морей в ту пору приобрел прерывистое распространение. На берегах Охотского моря температура воздуха была около $0^{\circ} \mathrm{C}$, а вблизи Охотско-Колымского водораздела от -3 до $-5^{\circ} \mathrm{C}$. КВ, видимо, имел островной или прерывистый характер. Суммарно осадки в казанцевский термохрон достигали 600-700 мм в год.

Примерно 100 тыс. л. н. проявились похолодание климата, отразившееся в понижении среднегодовых температур до $-23^{\circ} \mathrm{C}$ и регрессии моря, сокращение атмосферных осадков до 200 мм/год и меньше. КВ стал сплошным. В промежутке 7550 тыс. л. н. (каргинский интергляциал?) похолодание сменилось относительным потеплением. В этот промежуток среднегодовые температуры воздуха поднялись на $2-2.5^{\circ} \mathrm{C}$, но оставались значительно ниже современных. Годовое количество осадков возросло до 240 мм. Одновременно приостановилась и регрессия моря (Хопкинс, 1976). Характер КВ оставался сплошным. На отсутствие признаков деградации КВ указывают данные о непрерывном образовании сингенетичных повторно-жильных льдов и накопление лессов в течение всего криохрона. Термокарстовая активность началась только в раннем голоцене (Murton et al., 2015). Из-за возросших атмосферных осадков активизировался рост ледников, поэтому рассматриваемый промежуток позднего плейстоцена реально отвечает понятию ледникового (Котов, 2002; Галанин, 2012).

В последующем климат становится не только холоднее, но и засушливее. В среднем количество осадков было меньше 100 мм/год. Ледники сокращались за счет испарения, преобладали эоловые и криогенные процессы. Регрессия моря достигла минимальных значений около 20 тыс. л. н. Количественная оценка этого уровня имеет весьма широкие значения - от 100 до 200 м. Столь значительные расхождения, вероятно, связаны с активностью разнонаправленных тектонических движений на морском побережье.

Около 18 тыс. л. н. стал повышаться уровень моря (Хопкинс, 1976), а с рубежа 12.2 тыс. л. н. начался голоценовый термохрон, сказавший-

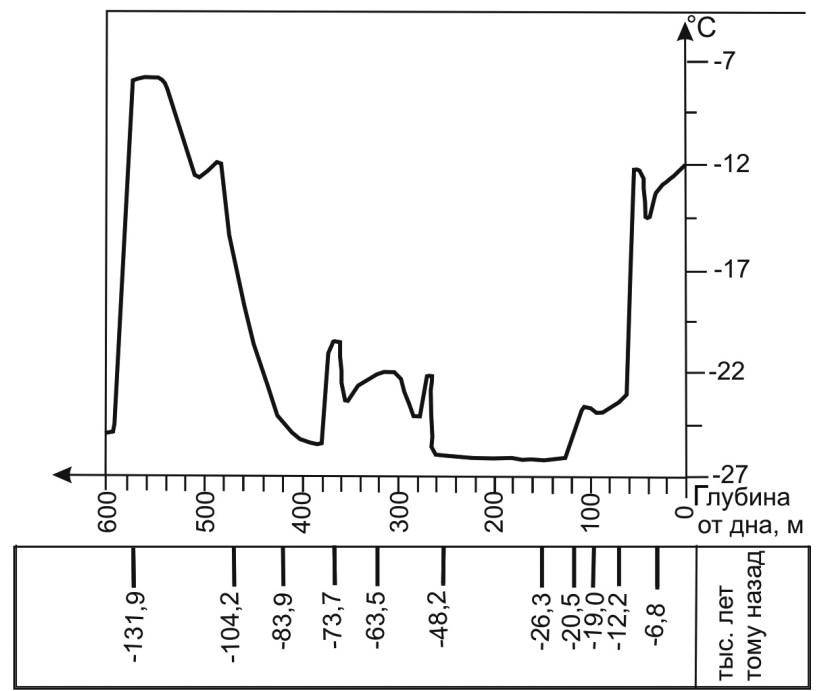

Puc. 2. Изменения среднегодовой температуры воздуха в Центральной Чукотке

Fig. 2. Annual air temperature changes in Central Chukotka

ся в резком потеплении климата и увеличении количества осадков. К периоду между 12 и 11 тыс. л. н. при отметке уровня моря от -37 до -45 м, вероятно, возник Берингов пролив (Ложкин, 2002) и восстановилась гидротермодинамическая связь Северного Ледовитого и Тихого океанов, создались условия для формирования климата в обстановке, близкой к современной (Васильчук, 2012).

О гидрогеологических процессах, связанных с изменениями природной среды в позднем плейстоцене - голоцене, свидетельствуют сохранившиеся до сих пор показатели.

\section{ПАЛЕОГИДРОГЕОЛОГИЧЕСКИЕ \\ СЛЕДСТВИЯ ПОЗДНЕЧЕТВЕРТИЧНЫХ ИЗМЕНЕНИЙ ПРИРОДНОЙ СРЕДЫ}

Палеогидрогеологические, по своим значениям парадоксальные, показатели разделены нами на гидрогеостатические и гидрогеохимические.

Гидрогеостатическими считаем аномально низкие уровни воды (АНУВ) в ее локальных скоплениях, т. е. статические уровни подземных вод в этих скоплениях, приведенные к плотно-

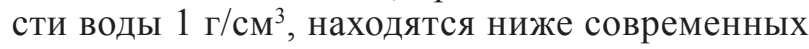
минимальных отметок области разгрузки конкретной гидрогеологической структуры. Такие скопления известны на Чукотке, в верховьях р. Колыма, на побережье Берингова моря. На морском побережье Чукотки водоносные объекты с уровнями подземных вод на 8-10 м ниже уровня моря встречены на глубинах до 40 м в песчаных линзах в толще льдистых суглинков. Водоносными являются пески четвертичного возраста. Воды представлены хло- 
ридными рассолами с минерализацией больше 50 г/л и температурой $-7.5^{\circ} \mathrm{C}$ (криопэги).

При разведке угольных месторождений в Аркагалинском и Индигиро-Зырянском артезианских бассейнах (АБ) неоднократно встречались подмерзлотные скопления подземных вод с аномально низкими уровнями. Величина гидростатических аномалий варьировала от -17 до -25 м относительно русла p. Аркагала в одноименном АБ (Глотов, 2009) и 80-110 м относительно русла p. Колыма в Индигиро-Зырянском АБ (Елисафенко, 1988). В обоих случаях водоносными являлись пласты трещиноватых углей и трещиннопористых песчаников мелового возраста. Проявления АНУВ отмечены на побережьях и на шельфе Восточно-Сибирского моря (табл. 1).

Признаками значительного понижения уровня подземных вод относительно современных отметок являются линзы и прослои отрицательно температурных рыхлых пород без льда-цемента - «сушенцы или морозные породы», подстилаемые и перекрываемые слоями льдистых глинистых пород. «Сушенцы» встречаются при проходке шахт для добычи золотоносных отложений и при бурении скважин ударно-канатным способом в межгорных впадинах. Например, они развиты в Момонтайском АБ, расположенном в осевой части хребта Черского с отметками поверхности АБ 1050-1200 м выше уровня моря. Осадочный чехол мощностью до 500 м представлен неогенплейстоценовыми песчано-галечными отложениями, переслаивающимися с песками, суглинками озерного и озерно-аллювиального происхождения. Мощность сплошного КВ до 180 м. «Сушенцы» залегают в интервале от 70 до 115 м. Их температура от -3.2 до $-1.2^{\circ} \mathrm{C}$. Наличие «сушенцов» в толще льдистых суглинков, по словам геофизика Г. И. Рощина, было неожиданно и необъяснимо.
При бурении скважин и проходке подземных горных выработок неоднократно встречались изолированные «сухие полости» в толще мерзлых пород. Одна из них описана геологом Н. И. Кривцовым в отчете за 1946 г. Полость была вскрыта шахтой № 16 в пойме р. Мальдяк в толще юрских песчано-глинистых сланцев. Ее видимая длина 18 м, ширина до 3 м, глубина до 8 м; глубже засыпана песчано-щебенчатым материалом. На присутствие подобных полостей в толще многолетнемерзлых пород (ТММП) указывают и многочисленные случаи поглощения промывочной жидкости при бурении скважин в мерзлых породах.

С геологических позиций сложно объяснить возникновение в естественных условиях пластов пород, обожженных при подземном горении ископаемых углей («горельники»). Обнажения таких пород на водоразделах, называемые геологами «гривками», распространены в центральном участке Индигиро-Зырянского АБ, характеризующемся сглаженным низкогорьем с абсолютными отметками днищ речных долин около 190200 м. При разведке месторождений угля «горельники» прослежены до глубин 100-120 м ниже днища речных долин, т. е. до абсолютных отметок 80-90 м при положении подошвы КВ на отметках ниже современного уровня моря на 50 м (Попов, 1962). Их наличие однозначно свидетельствует о региональной сработке ресурсов подземных вод в криохроне, так как более ранние образования были бы уничтожены процессами эрозии в казанцевском термохроне.

Гидрогеохимические показатели позднеплейстоценовых похолоданий и регрессии уровня моря известны практически по всей территории СВ РФ как в артезианских бассейнах, так и в гидрогеологических массивах в виде реликтов криогенного преобразования. Обычно такие реликты представлены подземными водами пре-

Таблица 1. Данные о подземных водах на шельфе Восточно-Сибирского моря (по материалам Я. В. Неизвестнова, 1981)

Table 1. Ground water data for the East Siberian Sea shelf (according to Ya. V. Neizvestnov, 1981)

\begin{tabular}{|c|c|c|c|}
\hline $\begin{array}{l}\text { Местоположение, } \\
\text { водопункт }\end{array}$ & $\begin{array}{c}\text { Интервал вскрытия, м от дна; } \\
\text { водоносные породы }\end{array}$ & $\begin{array}{c}\text { Статический } \\
\text { уровень } \\
\text { от современного } \\
\text { уровня моря }\end{array}$ & $\begin{array}{c}\text { Физические и химические характеристики } \\
\text { воды (Т - температура) }\end{array}$ \\
\hline $\begin{array}{l}\text { Пролив Лонга, } \\
\text { скважина }\end{array}$ & $\begin{array}{l}\text { 43.2-53.2; гравелистые } \\
\text { пески } \mathrm{Pg}_{3}-\mathrm{N}_{1}\end{array}$ & -10.4 & $\mathrm{M} 1.1 \frac{\mathrm{Cl} 69}{(\mathrm{Na}+\mathrm{K}) 52 \mathrm{Mg} 31 \mathrm{Ca} 17} ; \mathrm{T}=0.1^{\circ} \mathrm{C}$ \\
\hline $\begin{array}{l}\text { Побережье, о. Мал. } \\
\text { Ляховский, скважина }\end{array}$ & $\begin{array}{l}\text { 94-100.8; трещиноватые } \\
\text { аргиллиты } \mathrm{J}_{3}-\mathrm{K}_{1}\end{array}$ & -8.9 & $\mathrm{M} 3.6 \frac{\mathrm{C} 192}{(\mathrm{Na}+\mathrm{K}) 47 \mathrm{Mg} 27 \mathrm{Ca} 26} ; \mathrm{T}=-0.3^{\circ} \mathrm{C}$ \\
\hline $\begin{array}{l}\text { Побережье, о. Бол. } \\
\text { Ляховский, скважина }\end{array}$ & $60-122 ;$ пески $\mathrm{Pg}_{3}-\mathrm{N}_{1}$ & -2.5 & $\mathrm{M} 10.9 \frac{\mathrm{Cl} 97}{(\mathrm{Na}+\mathrm{K}) 84 \mathrm{Mg10}} ; \mathrm{T}=-0.8^{\circ} \mathrm{C}$ \\
\hline $\begin{array}{l}\text { Пролив Санникова, } \\
\text { скважина }\end{array}$ & $\begin{array}{l}\text { 16.1-53.5; пылеватые } \\
\text { пески } \mathrm{Q}_{1}-\mathrm{Q}_{3}\end{array}$ & 0 & $\mathrm{M} 19.6 \frac{\mathrm{C} 190}{(\mathrm{Na}+\mathrm{K}) 77 \mathrm{Mg} 18} ; \mathrm{T}=-0.8^{\circ} \mathrm{C}$ \\
\hline
\end{tabular}


имущественно хлоридного класса. При отсутствии солеродных формаций в регионе наличие хлоридных вод, при концентрации хлора в них больше, чем в морской воде, однозначно свидетельствует о вымораживании морской воды единственного источника хлор-иона. В табл. 2 приведены данные по наиболее репрезентативным пунктам на побережье арктических морей. В геологическом отношении во всех случаях это обводненные пески с галькой в иловатых толщах четвертичного возраста с аномально низкими уровнями.

В артезианских бассейнах (АБ), сформировавшихся в гумидных континентальных обстановках в кайнозое, рассолы хлоридного состава впервые были вскрыты М. Н. Мельниковым в 1956 г. в палеогеновых отложениях при разведке Анадырского буроугольного месторождения. Минерализация воды в отдельных скважинах достигала 95.2 г/дм³ . Вода находилась в литологически изолированных линзах, ее современный уровень, приведенный к плотности морской воды, был -5.65 м.

Интерес вызывают и проявления подмерзлотных хлоридных натриевых вод, вскрытых в долине р. Зырянка в угленосных отложениях в изолированном от моря Индигиро-Зырянском АБ. Их состав отражен в усредненной формуле: М5.5-6.9 С190-93/(Na + K)98. Фоновый состав подмерзлотных вод в этом АБ гидрокарбонатный натриевый с минерализацией не выше 3 г/дм³. Учитывая отсутствие связи АБ с морем, можно полагать, что наличие очаговых проявлений солоноватых хлоридных вод связано с их подтоком из более глубоких водоносных комплексов, например, палеозойских карбонатных пород в периоды понижения пластовых давлений в подмерзлотных горизонтах.

На побережье Охотского моря внутримерзлотные криопэги не встречены, но подмерзлот- ные хлоридные воды от пресных до солоноватых распространены широко (табл. 3).

Холодные подмерзлотные хлоридные воды с минерализацией менее 10 г/дм³ в Гижигинской и Кухтуйской угленосных впадинах описаны нами ранее (Глотов, Глотова, 2015).

В гидрогеологических массивах криопэги хлоридного и сульфатно-хлоридного состава вскрыты при отработке рудных месторождений в гранитных интрузиях, например, на Валькумейском оловорудном месторождении (Глотов, Глотова, 2003), при разведке Дегдеканского золоторудного (Абрамов и др., 2010) и на других объектах.

Подземные воды хлоридного состава с минерализацией 1.5-6.5 г/дм³ установлены и в Магаданском гранодиоритовом массиве в удалении от берега Охотского моря на 24 км. Температура воды не выше $5^{\circ} \mathrm{C}$. Воды залегают на глубине до 200 м в зоне тектонического разлома, к которому приурочена долина р. Дукча.

Показателем происходивших в позднем плейстоцене и голоцене изменений климата и уровня моря мы считаем и хлоридные воды термальных источников. В геологическом отношении эти источники приурочены к массивам магматогенных интрузивных и эффузивных пород, палеозойским и допалеозойским блокам регионально метаморфизованных терригенных и карбонатных образований (табл. 4). Установлено, что со времени их открытия (60-70 лет назад) состав и температура их практически не меняются.

Поскольку на СВ РФ значимым поставщиком хлор-иона является только море, можно заключить, что теплоносителем в источниках первой группы служит морская вода, которая по мере приближения к месту разгрузки разбавляется метеогенной пресной. Процесс фильтрации воды в зоны разлома из моря, ее нагревание в недрах и разбавление пресными хлоридными водами в очаге разгрузки термальных вод во времени стабильны.

Таблица 2. Внутримерзлотные криопэги на арктическом побережье (по материалам А. А. Архангелова, Л. А. Жихарева, 1974 г.; М. К. Шумихиной, 1981 г.)

Table 2. Intrapermafrost cryopegs on the Arctic coast (according to A. A. Arhanghelov and L. A. Zhikharev, 1974; M. K. Shumikhina, 1981)

\begin{tabular}{|c|l|c|c|c|}
\hline $\begin{array}{c}\text { № } \\
\text { п/п }\end{array}$ & $\begin{array}{c}\text { Местоположение скважины, } \\
\text { абс. отметка устья, м; } \\
\text { глубина, м }\end{array}$ & $\begin{array}{c}\text { Интервал } \\
\text { опробования }\end{array}$ & $\begin{array}{c}\text { Стат. уровень, м: перед } \\
\text { чертой - замеренный, после }- \\
\text { приведен к морской воде }\end{array}$ & $\begin{array}{c}\text { Формула химического } \\
\text { состава; } \mathrm{pH} ; \\
\text { температура }\end{array}$ \\
\hline 1 & $\begin{array}{l}\text { Чаунская губа, морская } \\
\text { коса; 10.5; 91 }\end{array}$ & $28-91$ & $-8 /-7.8$ & $\mathrm{M} 54 \frac{\mathrm{Cl} 94}{(\mathrm{Na}+\mathrm{K}) 78 \mathrm{Mg} 13}$ \\
\hline 2 & $\begin{array}{l}\text { Чукотское море, лагуна } \\
\text { Рыпельхин; 200 м от } \\
\text { берега; 5; 65 }\end{array}$ & $41-65$ & $-33.5 /-31$ & $\mathrm{M} 130 \frac{\mathrm{Cl} 95}{(\mathrm{Na}+\mathrm{K}) 80 \mathrm{Mg} 14}$ \\
\hline 3 & Там же, берег лагуны; 1;22 & $12-22$ & $-9.5 /-8.4$ & $\mathrm{pH} 7.6 ;-8^{\circ} \mathrm{C}$ \\
\hline
\end{tabular}


Таблица 3. Сведения о водах хлоридного класса в континентальных отложениях кайнозойских впадин на северном побережье Охотского моря (по материалам В. Я. Зинченко, 1972 г.; В. И. Михеева, В. М. Иванова, 1962 г.; В. В. Осинцева, 1981 г.)

Table 3. Data on chloride waters in continental deposits of Cenozoic depressions on the Sea of Okhotsk northern coast (according to V. Y. Zinchenko, 1972; V. I. Mikheev and V. M. Ivanov, 1962; V. V. Osintsev, 1981)

\begin{tabular}{|c|c|c|}
\hline Общие сведения об объекте опробования & $\begin{array}{c}\text { Интервал } \\
\text { опробования, м }\end{array}$ & $\begin{array}{c}\text { Формула химического состава; } \\
\text { температура воды; рН }\end{array}$ \\
\hline $\begin{array}{l}\text { Скважина в Хасын-Уптарской межгорной впа- } \\
\text { дине. Отметка устья } 200 \text { м, глубина } 317.6 \text { м. } \\
\text { Вскрыты неогеновые отложения }\end{array}$ & $159-316$ & $\begin{array}{l}\mathrm{M} 0.46 \frac{\mathrm{Cl}_{2} \mathrm{SO}_{4} 19}{(\mathrm{Na}+\mathrm{K}) 91} \\
\mathrm{~T}=5.2^{\circ} \mathrm{C} ; \mathrm{pH} 6.6\end{array}$ \\
\hline $\begin{array}{l}\text { Скважина в долине р. Магаданка, в } 2.5 \text { км от } \\
\text { берега моря, в Магаданской впадине. Отметка } \\
\text { устья } 2.5 \text { м, глубина } 320 \text { м. Вскрыты неогеновые } \\
\text { отложения }\end{array}$ & $177-258$ & $\begin{array}{c}\mathrm{M} 0.63 \frac{\mathrm{Cl} 92}{(\mathrm{Na}+\mathrm{K}) 51 \mathrm{Ca} 32 \mathrm{Mgl} 1} ; \\
\mathrm{T}=4.7^{\circ} \mathrm{C} ; \mathrm{pH} 8.0\end{array}$ \\
\hline $\begin{array}{l}\text { Скважина в долине р. Танон в Ольской впадине, } \\
\text { в } 15 \text { км от берега моря. Отметка устья } 16 \text { м, глу- } \\
\text { бина } 400 \text { м. Вскрыты плиоценовые отложения }\end{array}$ & $240-320$ & $\begin{array}{c}\mathrm{M} 3.6 \frac{\mathrm{Cl} 99}{(\mathrm{Na}+\mathrm{K}) 57 \mathrm{Ca} 40} \\
\mathrm{~T}=5^{\circ} \mathrm{C} ; \mathrm{pH} 7.2\end{array}$ \\
\hline $\begin{array}{l}\text { Скважина на берегу Охотского моря в } 2.6 \text { км } \\
\text { восточнее устья р. Ола. Отметка устья } 2.7 \text { м, } \\
\text { глубина } 400 \text { м. Вскрыты миоценовые отложения }\end{array}$ & $166-269$ & 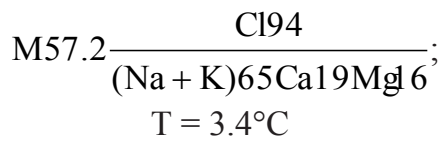 \\
\hline
\end{tabular}

Таблица 4. Температура, минерализация и содержание хлор-иона в термальных источниках (Гидрогеология..., 1972)

Table 4. Temperature, mineralization, and chlorine ion content in thermal sources (Hydrogeology..., 1972)

\begin{tabular}{|c|c|c|c|}
\hline Источник, общие сведения & $\begin{array}{c}\text { Температура, } \\
{ }^{\circ} \mathrm{C}\end{array}$ & $\begin{array}{l}\text { Общая минера- } \\
\text { лизация, г/дм }\end{array}$ & $\begin{array}{c}\text { Содержание } \\
\text { хлор-иона, } \\
\text { г/дм }\end{array}$ \\
\hline \multicolumn{4}{|c|}{ Северное побережье Охотского моря } \\
\hline $\begin{array}{l}\text { Березовый, среднее тече- } \\
\text { ние р. Широкая }\end{array}$ & 22 & 1.8 & 0.94 \\
\hline $\begin{array}{l}\text { Мотыклейский, бассейн } \\
\text { p. Улукан }\end{array}$ & 43 & 5.1 & 3.1 \\
\hline $\begin{array}{l}\text { Таватумский, в пойме } \\
\text { руч. Холоткан }\end{array}$ & 61 & 16.5 & 9.3 \\
\hline \multicolumn{4}{|c|}{ Побережье Берингова моря } \\
\hline $\begin{array}{l}\text { Чаплинский, долина } \\
\text { р. Ульхум }\end{array}$ & 94.6 & 18.7 & 11 \\
\hline $\begin{array}{l}\text { Кукунский, побережье } \\
\text { зал. Лаврентия }\end{array}$ & 61 & 4.5 & 2.51 \\
\hline Кивакский, лаг. Кивак & 35.5 & 3 & 1.69 \\
\hline
\end{tabular}

ются устойчивым во времени режимом состава и температуры. Это указывает на стабильность процесса инфильтрации современной морской воды в недра к источникам тепла, которыми являются плиоцен-четвертичные дайки (Кораго, Евдокимов, 1999). Для проникновения воды из моря к этим дайкам необходимо, чтобы давление столба морской воды превышало давление столба пресной метеогенной в пределах суши. В современных условиях, за исключением низменных морских побережий, данное требование невыполнимо. Установлены очаги разгрузка пресных подземных вод на шельфе у северного побере-

\section{ОБСУЖДЕНИЕ РЕЗУЛЬТАТОВ ИССЛЕДОВАНИЯ}

Выявление гидрогеологической роли позднечетвертичных изменений природных условий рационально начать с восстановления механизма образования гидротермальных источников на морских побережьях. Все они приурочены к гидрогеологическим массивам, в которых нет условий для аккумуляции в недрах значительных запасов подземных вод. Вместе с тем они отличажья Охотского моря (Глотов, Глотова, 2014). Не было условий для инфильтрации морской воды в недра континента и в казанцевский термохрон, когда климатические условия были более оптимальными для питания подземных вод, нежели в голоцене. Поэтому можно утверждать, что источники термальных хлоридных вод возникли в современное время. Для обоснования этого утверждения рассмотрим особенности гидрогеологических условий в последнем криохроне и в текущем термохроне. 
Понижение уровня моря и ужесточение климатических условий, начавшиеся около 100 тыс. л. н., способствовали прогрессивному росту мощности КВ, перемерзанию водопоглощающих таликов, падению уровня подземных вод. Распространенность сушенцов в межгорных впадинах и в зонах разломов в скальных породах, горельников в Индигиро-Зырянском артезианском бассейне говорит о том, что понижение уровня подземных вод опережало промерзание. Незначительное повышение температуры воздуха и возможная стабилизация уровня моря в каргинский интерстадиал могли отразиться на замедлении процессов увеличения мощности ТММП и скорости падения уровня подземных вод,

В криохрон даже крупные реки с водосборной площадью до 100 тыс. км², возможно, и больше, не имели зимнего стока, а в руслах рек с водосборной площадью до 50 тыс. км ${ }^{2}$ в теплое время года существовали цепи озер, донные осадки которых промерзали сингенетично. Такое заключение было сделано на основе криофациальных исследований в долине р. Майн (бассейн р. Анадырь) А. Н. Котовым и В. К. Рябчуном (1986). Следовательно, сквозные подрусловые водопоглощающие талики перемерзали. Возможно, существовали сквозные водовыводящие талики под руслами нижних течений крупных рек (Анадырь, Колыма, Индигирка, Пенжина, Тауй) и на площади шельфа. На современной суше сложился не наблюдаемый ныне длительный режим региональной сработки ресурсов подземных вод во всех гидрогеологических структурах. Этот режим продолжался не менее 60 тыс. лет до начала трансгрессии моря в конце позднего плейстоцена. Судя по наличию рассолов на глубине 269 м на берегу Охотского моря, блоков многолетнемерзлых пород мощностью до 400 м в бассейне р. Ола (Зуев, 1995), общая глубина промерзания достигала примерно 600 м. До этой глубины понижались и уровни подмерзлотных вод (Глотов, 2009).

Начавшаяся около 18 тыс. л. н. трансгрессия моря сопровождалась проникновением в недра континента морских вод при повышении температуры пород выше $-1.9^{\circ} \mathrm{C}$. При отсутствии на суше сквозных водопоглощающих таликов моря стали основными областями питания подмерзлотных вод. По нашим представлениям, специфический режим восполнения ресурсов подземных вод без их расхода существовал с 18 тыс. л. н. до конца пребореальной стадии (около 10-9 тыс. л. н.), когда климатические условия стали сходны с современными (Васильчук, 2012). За это время талассогенные воды проникли далеко в сушу, о чем свидетельствует существование хлоридных вод в Уптарском АБ в 45 км от северного берега Охотского моря. В бореальный период при оптимальных климатических условиях под руслами рек и под озерами сформировались сквозные водопоглощающие талики. Начался процесс вытеснения талассогенных вод пресными как из пластовых, так из трещинных и трещинно-жильных подземных емкостей. Режим формирования подземных вод приобрел современные черты. Одновременно с климатическими изменениями происходили активные неотектонические процессы, при которых создался современный облик морских побережий и горных стран, восстановился Берингов пролив, происходило внедрение даек базальтов (Кораго, Евдокимов, 1999; Смирнов, 2012).

С позднеплейстоцен-голоценовым внедрением морских вод по зонам разломов в недра гидрогеологических массивов мы увязываем возникновение источников термальных хлоридных вод в долинах водотоков на удалении до 1012 км от морских берегов. Нагрев подземных вод может происходить за счет внутреннего тепла Земли и/или тепла внедрившихся в четвертичное время базальтовых даек. При реализации первого предположения источники термальных вод могли бы наблюдаться в зонах всех глубинных разломов. Фактически эти источники редки, поэтому мы считаем, что очаги разгрузки термальных вод свидетельствуют о нахождении в зонах обводненных разломов четвертичных базальтовых даек. Есть косвенные свидетельства исторически недавнего происхождения гидротермальных источников. Так, в топонимическом словаре В. В. Леонтьева и К. А. Новиковой (1989) отсутствуют названия водных объектов, которые можно перевести с языка коренных народов Севера на русский как теплый, горячий или с другим отличительным признаком. В гидрогеологических массивах, в разломах при внедрении и кристаллизации базальтовой магмы происходил не только нагрев вмещающих пород, но и увеличение трещиноватости в экзоконтактных зонах. Эти зоны, открываясь в приуроченных к разломам долинах водотоков, становились локальными очагами пьзоминимумов, к которым направлен поток как талассогенных, так и метеогенных вод. Это позволяет сохраняться современному потоку морской воды в недра суши и участвовать в питании термальных источников. Существование таких потоков морской воды к очагам магматического тепла доказано на Камчатке (Кирюхин и др., 2010). При отсутствии четвертичных даек базальтов в зонах субмеридиональных разломов в гидрогеологических массивах, омываемых морем, могут залегать холодные хлоридные воды, которые источников не формируют.

\section{ЗАКЛЮЧЕНИЕ}

Таким образом, в истории формирования подземных вод на Северо-Востоке России в позднечетвертичное время и в голоцене отчетливо вы- 
деляются два этапа, соответствующие позднеплейстоценовому криохрону и голоценовому термохрону.

В этап криохрона, длившийся около 80 тыс. лет, сложился регрессивный режим регионального срабатывания ресурсов подземных вод. Геостатическими показателями этого режима являются: существование линз внутри- и подмерзлотных подземных вод с аномально низкими уровнями; сушенцы в АБ и в гидрогеологических массивах; слои горельников до глубин 100-120 м ниже современных отметок дневной поверхности в Индигиро-Зырянском угленосном бассейне. Гидрогеохимическими показателями регрессивного режима служат внутримерзлотные криопэги, подмерзлотные и внутримерзлотные соленые воды и рассолы хлоридного и сульфатного классов.

В составе этого этапа выделяем три стадии формирования подземных вод:

первая - понижение уровня опережает скорость наращивания мощности КВ из-за перемерзания сквозных таликов и регрессии моря. Эту стадию можно назвать стадией образования сушенцов и горельников. Ориентировочный интервал ее существования - от 100 до 75 тыс. л. н.;

вторая стадия соответствует времени относительного потепления от 75 до 50 тыс. л. Н. В эту стадию скорость промерзания литосферы и падения уровня подземных вод выровнялись изза относительного потепления и уменьшения скорости понижения уровня подземных вод;

третья стадия, соответствующая периоду от 50 до 18 тыс. л. н., характеризуется опережением скорости промерзания литосферы над скоростью понижения уровня подземных вод. В гидрогеологических структурах появился криогенный напор, выдавливающий подземные воды в окружающие моря.

В период перехода от криохрона к современному термохрону, примерно от 18 до 9 тыс. л. н. существовал этап ингрессивного режима. Его особенность - отсутствие областей разгрузки подземных вод до конца пребореальной стадии голоценового периода. Господствовали процессы инфильтрации в недра суши из акватории наступающего моря, чему способствовал большой дефицит напоров подземных вод. В последующем периоде и до современного формируются сквозные водопоглощающие и водовыводящие талики в речных долинах, под озерами и т. д., господствует этап равновесного режима подземных вод. Следы ингрессивного режима: пластовые хлоридные воды, от пресных до солоноватых и рассолов, в АБ, в том числе замкнутых межгорных, с кайнозойским пресноводным осадочным чехлом; современные локальные потоки морских вод в недра континента к очагам тепла в гидрогеологических массивах, питающие источники термальных вод.

Обратим внимание на то, что изложенные авторские представления об особенностях гидрогеологической истории в позднем плейстоцене и голоцене касаются только подземных вод зон активного (свободного) и замедленного (затрудненного) водообмена, энергетический потенциал которых определяется разностью приведенных напоров в областях питания и разгрузки подземных вод. Кроме того, Северо-Восток России занимает полуостровное положение, находясь в зоне взаимодействия двух Мировых океанов. Поэтому гидрогеологическая история региона может иметь свои особенности, отличные от особенностей регионов в зоне влияния Атлантического океана.

Выявленные закономерности могут быть использованы для более глубокого изучения процессов влияния происходящих природных изменений на жизнедеятельность людей.

\section{БЛАГОДАРНОСТИ}

Автор выражает свою благодарность к. г. н., ведущему научному сотруднику СВКНИИ ДВО РАН А. В. Ложкину за консультации по вопросам связи растительного покрова с климатическими изменениями и особенностям периодизации позднекайнозойской истории Земли, ст. н. с. СВКНИИ ДВО РАН Л. П. Глотовой за помощь в подборе материалов и оформлении статьи.

Исследование выполнено при финансовой поддержке РФФИ в рамках научного проекта № 18-0560036.

\section{ЛИТЕРАТУРА}

Абрамов В. Ю. Криогенная метаморфизация химического состава подземных вод // Разведка и охрана недр. 2014. № 5. С. 16-20.

Абрамов В. Ю., Вавичкин А. Ю., Щипанский А. А., Апанасенко Д. С. Криогидрогеохимические условия золоторудного месторождения Дегдекан // Разведка и охрана недр. 2010. № 10. С. 52-56.

Алексеев С. В. Криогидрогеологические системы Якутской алмазоносной провинции. Новосибирск : Гео, 2009. 319 c.

Алексеева Л. П. Геохимия подземных льдов, соленых вод и рассолов Западной Якутии : дис. ... д-ра геол.-минер. наук. Иркутск, 2015. 229 с.

Андерсон П. М., Ложкин А. В. Предисловие к пыльцевым летописям озерных отложений Берингии // Климатические летописи в четвертичных осадках Берингии. Магадан : СВКНИИ ДВО РАН, 2004. C. 4-26.

Боревский Б. В., Язвин А. Л., Черепановский М. М. Экспертные оценки ресурсного потенциала подземных вод при разработке схем комплексного использования и охраны водных ресурсов // Разведка и охрана недр. 2014. № 5. С. 29-32.

Васильчук Ю. К., Буданцева Н. А., Бартова А. В., Зимов C. A. Вариации стабильных изотопов кисло- 
рода в повторно-жильных льдах циклитной едомы Станчиковского Яра на реке Малый Анюй // Арктика и Атлантика. WoS N03 37-56 DOI:107256/24538922.2018.3.27121. URL: http://e-nota bene.ru/ arcticle_27121.html

Васильчук Ю. К. Рубеж плейстоцена и голоцена около 10 тысяч лет назад - время коренной смены типичных геокриологических образований // Криосфера Земли. 2012. Т. 16, № 3. С. 29-38.

Васьковский А. П., Терехова В. Е. Антропогеновая (четвертичная) система // Геология СССР. Т. 30. Северо-Восток СССР. Геологическое описание. Кн. 1. М. : Недра, 1970. С. 501-547.

Галанин A. A. Возраст последнего ледникового максимума на северо-востоке Азии // Криосфера Земли. 2012. Т. 16, № 3. С. 39-52.

Гинзбург Г. Д., Гуревич А. Е., Резник А. Д. О причинах низких пластовых давлений на севере Сибири // Сов. геология. 1971. № 9. С. 45-58.

Глотов В. Е., Глотова Л. П. Геокриологические и гидрогеологические усковия угленосных площадей на северном побережье Охотского моря // Криосфера Земли. 2015. Т. 21, № 1. С. 3-10.

Глотов В. Е. Гидрогеология осадочных бассейнов Северо-Востока России. Магадан : Кордис, 2009. 232 с.

Глотов В. Е., Глотова Л. П. Подземные воды Валькумейского оловорудного месторождения // Колыма. 2003. № 2. С. 21-28.

Глотов В. Е., Глотова Л. П. Химические показатели водообмена в Североохотоморской прибрежной зоне // Вода: химия и экология. 2014. № 10. С. 24 31.

Елисафенко T. Н. Закономерности криогенного преобразования толщ пород и подземных вод угольных бассейнов Дальнего Востока : автореф. ... канд. геол.-минер. наук. М., 1988. 29 с.

Зуев И. А. Геокриологические, геотермические и сейсмические особенности Приохотской рифтовой зоны в районе Тауйской губы // Колыма. 1995. № 9-10. C. 8-15.

Кирюхин А. В., Кирюхин В. А., Манухин Ю. Ф. Гидрогеология вулканогенов. СПб. : Наука, 2010. 395 с.

Кораго Е. Н., Евдокимов А. Н. Постмиоценовый континентальный щелочно-базальтовый вулканизм Северной Евразии // Петрология. 1999. Т. 7, № 1. C. $80-98$.

Котов А. Н., Рябчун В. К. Криогенный комплекс позднеплейстоценовых отложений долины р. Майн : в 2-х ч. Ч. 1. Ледовый обрыв. Ч. 2. Усть-Алганское обнажение и Мамонтов обрыв : препринт. Магадан : СВКНИИ ДВНЦ АН СССР, 1986. 106 с.

Котов A. Н. Плейстоценовые оледенения южной части Нижнеанадырской впадины и севера Корякского нагорья // Четвертичная палеогеография Берингии. Магадан : СВКНИИ ДВО РАН, 2002. С. 67-75.

Леонтьев В. В., Новикова К. А. Топонимический словарь Северо-Востока СССР. Магадан: Кн. изд-во, 1987. $456 \mathrm{c}$.

Ложкин A. В. Границы Берингии в позднем плейстоцене // Там же. С. 4-12.

Поступила в редакцию 16.09.2019 2.

Поступила после доработки 22.10.2019 г.
Матросова Т. В., Андерсон П. М., Ложкин А. В., Минюк П. С. Климатическая история Чукотки за последние 300 тыс. лет по данным пыльцевой летописи оз. Эльгыгытгын // Климатические летописи в четвертичных осадках Берингии. Магадан : СВКНИИ ДВО PAH, 2004. C. 26-42.

Мельников В. П. К созданию цельного образа криосферы // Криосфера Земли. 2014. Т. 18, № 4. C. 3-12.

Неизвестнов Я. В. Мерзлотно-гидрогеологические условия зоны арктических шельфов СССР // Криолитозона арктического шельфа. Якутск : ИМ СО РАН, 1981. C. 18-28.

Позднечетвертичные растительность и климаты Сибири и Российского Дальнего Востока (палинологическая и радиоуглеродная база данных) / под ред. П. М. Андерсон и А. В. Ложкина. Магадан : СВНЦ ДВО РАН, 2002. 370 с.

Попов Г. Г. Зырянский каменноугольный бассейн // Геология месторождений угля и горючих сланцев СССР. Т. 10. Угольные бассейны и месторождения Северо-Востока СССР и Камчатки. М. : Госгеолтехиздат, 1962. С. 32-105.

Свойства материалов и веществ. Вода и водяной пар. Вып. 1. Таблицы стандартных справочных данных. М. : Изд-во стандартов, 1990. 156 с.

Сергин С. Я., Щеглова М. С. Климат Берингии в ледниковые этапы как следствие влияния местных и глобальных факторов // Берингия в кайнозое : материалы Всесоюз. симп. «Берингийская суша в кайнозое» (Хабаровск, 10-15.05.1973 г.). Владивосток : ДВНЦ AH CCCP, 1976. C. 171-175.

Смирнов В. Н. Верхояно-Чукотская область новейшего горообразования: зональность и основные этапы формирования // Геология и геофизика. 2012. Т. 53, № 5. С. 610-620.

Фотиев С. М. Криогенный метаморфизм пород и подземных вод (условия и результаты). Новосибирск : Гео, 2009. 277 с.

Фотиев С. М. Подземные воды криогенной области России // Криосфера Земли. 2013. Т. 17, № 2. C. 41-59.

Хопкинс Д. М. История уровня моря в Берингии за последние 250 тыс. лет // Берингия в кайнозое : материалы Всесоюз. симп. Хабаровск, 10-15.05.1973 г. Владивосток : ДВНЦ АН СССР, 1976. С. 9-27.

Шепелев В. В., Толстихин О. Н., Пигузова В. М. Мерзлотно-гидрогеологические условия Восточной Сибири. Новосибирск : Наука, СО, 1984. 190 с.

Murton J. B., Goslar T., Edwards M. E., Bateman M. D., Danilov P. P., Savvinov G. N., Gubin S. V., Lupachev A. V., Ghhaleb B., Haile J., Kanevskiy M., Shur Y., Lozkin A. V., Murton D. K., Tikhonov A., Vasilchuk A. C., Vasilchuk Y. K., Wolfe S. A. Palaeoenvironmental interpretation of yedoma silt (ice complex) deposition as cold-climate loess, Duvanny Yar, Northeast Siberia // Permafrost and Periglacial Processes. 2015. Vol. 26. P. 208-288.

Nolan M., Cassano E. N., Cassano J. J. Synoptic Climatology and recent climate trends at Lake Elgygytgyn // Climate of the Past. 2013. 9. 1271-1286, WWW. clim-past.net/91271/2013/; doi: 10.5194/cp-9-1271-2013. 


\title{
FORMATION OF UNDERGROUND WATERS IN THE NORTH-EAST OF RUSSIA IN THE LATE QUATERNARY TIME
}

\begin{abstract}
V. E. Glotov
North-East Interdisciplinary Scientific Research Institute n. a. N. A. Shilo, FEB RAS, Magadan

According to paleogeographic and hydrogeological studies, the features of groundwater supply and discharge in the Late Pleistocene cryochron and in the Holocene thermochron are described. The author distinguishes the regressive mode (100 to 18 thousand yrs. B. P.), characterized by regional depletion of subsoil water resources; the ingressive mode (18-9 thousand yrs. B. P.), with predominant replenishment of water resources: and the contemporary mode, or the mode or equilibrium processes of groundwater recharging and discharging.
\end{abstract}

Keywords: North-East of Russia, groundwater formation, Late Pleistocene, cryochrons, thermochrons, paleohydrogeology.

\section{REFERENCES}

Abramov, V. Yu., 2014, Cryogenic Metamorphization of the Groundwater Chemical Composition, Prospect and Protection of Mineral Resources, 5, 16-20 [In Russian].

Abramov, V. Yu.; Vavichkin, A. Yu.; Shchipansky, A. A.; Apanasenko D. S., 2010, Cryohydrogeochemical Conditions of the Degdekan Gold Ore Deposit, Ibid., 10, 52-56 [In Russian].

Alekseev, S. V., 2009, Cryohydrogeological Systems of the Yakut Diamondiferous Province, Novosibirsk, Geo [In Russian].

Alekseeva, L. P., 2015, Geochemistry of Underground Ices, Salt Waters, and Brines of Western Yakutia, Dis... Dr. Sci. (Geology \& Mineralogy), Irkutsk [In Russian].

Anderson, P. M.; Lozhkin, A. V., 2004, Introduction to the Pollen Records of Beringia's Lake Sediments, Climatic Records in the Beringia Quaternary Sediments, Magadan, NECS FEB RAS, 4-26 [In Russian].

Borevsky, B. V.; Yazvin, A. L.; Cherepanovsky, M. M., 2014, Expert Assessments of the Groundwater Resource Potential in Developing Schemes for Integrated Use and Protection of Water Resources, Exploration and Protection of Subsurface Resources, 5, 29-32 [In Russian].

Fotiyev, S. M., 2009, Cryogenic Metamorphism of Rocks and Groundwaters (Conditions and Results), Novosibirsk, Geo [In Russian].

Fotiyev, S. M., 2013, Groundwaters of Russia's Cryogenic Area, Earth's Cryosphere, 17, 2, 41-59 [In Russian].

Galanin, A. A., 2012, Age of the Last Glacial Maximum in Northeast Asia, Ibid., 16, 3, 39-52 [In Russian].

Ginzburg, G. D.; Gurevich, A. E.; Reznik, A. D., 1971, On the Causes of Low Reservoir Pressures in the North of Siberia, Sovietskaya Geologiya, 9, 45-58 [In Russian].

Glotov, V. E., 2009, Hydrogeology of Sedimentary Basins in the North-East of Russia, Magadan, Cordis [In Russian].

Glotov, V. E.; Glotova, L. P., 2003, Groundwaters of the Valkumey Tin Ore Deposit, Kolyma, 2, 21-28 [In Russian].

Glotov, V. E.; Glotova, L. P., 2014, Chemical Indicators of Water Exchange in the North Okhotsk Coastal
Zone, Water: Chemistry and Ecology, 10, 24-31 [In Russian].

Glotov, V. Ye.; Glotova, L. P., 2015, Geocryological and Hydrogeological Conditions in Coal-Bearing Areas on the Sea of Okhotsk Northern Coast, Cryosphere of the Earth, 21 (1), 3-10 [In Russian].

Hopkins, D. M., 1976, The History of Sea Level in Beringia over the Past 250 Thousand Years, Beringia in the Cenozoic, Materials of the All-Union Symp. Khabarovs, May 10-15, 1973, Vladivostok, DVNC AS USSR, 9-27 [In Russian].

Kiryukhin, A. V.; Kiryukhin, V. A.; Manukhin, Yu. F., 2010, Hydrogeology of Volcanogens, St. Petersburg, Nauka [In Russian].

Korago, E. N.; Evdokimov, A. N., 1999, Post-Miocene Continental Alkaline-Basaltic Volcanism of Northern Eurasia, Petrology, 7, 1, 73-90 [In Russian].

Kotov, A. N., 2002, Pleistocene Glaciation of the Southern Part of the Lower Anadyr Depression and the North of the Koryak Upland, Beringa Quaternary Paleogeography, Magadan, NECS FEB RAS, 67-75 [In Russian].

Kotov, A. N.; Ryabchun, V. K., 1986, Cryogenic Complex of the Late Pleistocene Sediments of the Mine River Valley, In 2 parts, Part 1, Ice Clift. Part 2, Ust-Algan Outcrop and Mamontov Clift, Preprint, Magadan, SVKNII DVNC AN USSR [In Russian].

Late Quaternary Vegetation and Climates of Siberia and the Russian Far East (Palynological and Radiocarbon Database), Eds. P. M. Anderson and A. V. Lozhkin, Magadan, NESC FEB RAS, 2002 [In Russian].

Leontyev, V. V.; Novikova, K. A., 1987, Toponymic Dictionary of the USSR North-East, Magadan [In Russian].

Lozhkin, A. V., 2002, Beringia Boundaries in the Late Pleistocene, Beringia Quaternary Paleogeography, Magadan, NESC FEB RAS, 4-12 [In Russian].

Matrosova, T., V.; Anderson, P. M.; Lozhkin, A. V.; Minyuk, P. S., 2004, Climatic History of Chukotka over the Past 300 Thousand Years According to Lake El'gygytgyn Pollen Annals, Climatic Annals in the Quaternary Sediments of Beringia, Magadan, NEISRI FEB RAS, 26-42 [In Russian]. 
Melnikov, V. P., 2014, On Creating the Cryosphere Integral Image, Earth's Cryosphere, 18, 4, 3-12 [In Russian].

Murton, J. B.; Goslar, T.; Edwards, M. E.; Bateman, M. D.; Danilov, P. P.; Savvinov, G. N.; Gubin, S. V.; Lupachev, A. V.; Ghhaleb, B.; Haile, J.; Kanevskiy, M.; Shur, Y.; Lozkhin, A. V.; Murton, D. K.; Tikhonov, A.; Vasilchuk, A. C.; Vasilchuk, Y. K.; Wolfe, S. A., 2015, Palaeoenvironmental Interpretation of Yedoma Silt ( Ice Complex) Deposition as Cold-Climate Loess, Duvanny Yar, Northeast Siberia, Permafrost and Periglacial Processes, 26, 208-288.

Neizvestnov, Ya. V., 1981, Permafrost-Hydrogeological Conditions of the USSR Arctic Shelf Zone, Cryolithozone of the Arctic Shelf, Yakutsk, IM SB RAS, 18-28 [In Russian].

Nolan, M.; Cassano, E. N.; Cassano, J. J., 2013, Synoptic Climatology and Recent Climate Trends at Lake El'gygytgyn, Climate of the Past, 9, 1271-1286, WWW. clim-past.net/91271/2013/; DOI: 10.5194/cp-9-12712013.

Popov, G. G., 1962, Zyryanka Coal Basin, Geology of Coal Deposits and Oil Shales of the USSR, Vol. 10, Coal Basins and Deposits of the North-East of the USSR and Kamchatka, Moscow, Gosgeoltekhizdat, 32-105 [In Russian].

Properties of Materials and Substances. Water and Water Vapor, Vol. 1, Tables of Standard Reference Data, 1990, Moscow, Publishing House of Standards [In Russian].

Sergin, S. Ya.; Shcheglova, M. S., 1976, Climate of Beringia in the Ice Stages, as a Result of the Influence of Local and Global Factors, Beringia in the Cenozoic: $M a-$ terials of the All-Union. Symp. "Beringian Land in the Cenozoic” (Khabarovsk, May 10-15, 1973), Vladivostok, DVNC AN USSR, 171-175 [In Russian].

Shepelev, V. V.; Tolstikhin, O. N.; Piguzova, V. M., 1984, Permafrost-Hydrogeological Conditions of Eastern Siberia, Novosibirsk, Nauka, SB [In Russian].

Smirnov, V. N., 2012, Verkhoyansk-Chukotka Region of the Latest Mountain Formation: Zoning and the Main Stages of Formation, Russian Geology and Geophysics, 53, 5, 610-620 [In Russian].

Vasilchuk, Yu. K., 2012, Edge of the Pleistocene and Holocene - about 10 Thousand Years B.P. - the Time of the Radical Change of Typical Geocryological Formations, Earth's Cryosphere, 16, 3, 29-38 [In Russian].

Vasilchuk, Yu. K.; Budantseva, N. A.; Bartova, A. V.; Zimov, S. A., Variations of Stable Oxygen Isotopes in ReIce of the Stanchikovsky Yar Cyclite Edoma on the Maly Anyui River, Arctic and Atlantic, WoS N03 37-56 DOI: 107256 / 2453-8922.2018.3.27121. URL: http: // e-nota bene.ru/ arcticle 27121.html [In Russian].

Vas 'kovsky, A.P.; Terekhova, V.E., 1970,Anthropogenic (Quaternary) System. Geology of the USSR. Vol. 30. North-East of the USSR. Geological Description. Prince 1. Moscow, Nedra, 501-547 [In Russian].

Yelisafenko, T. N., 1988, Regularities in Cryogenic Transformation of Rock Strata and Groundwaters in Coal Basins of the Far East, Abstr. ... Cand. Sci. (Geology \& Mineralogy), Moscow [In Russian].

Zuyev, I. A., 1995, Geocryological, Geothermal, and Seismic Features of the Priokhotye Rift Zone in the Tauy Bay, Kolyma, 9-10, 8-15 [In Russian]. 